\title{
NOTES ON THE MATERIALITY AND SPIRITUALITY OF BOOKS AND THEIR BEING IN THE WORLD
}

\author{
DANA BĂDULESCU \\ CRISTINA GAVRILUȚĂ \\ Alexandru Ioan Cuza University of Iaşi, Romania
}

\begin{abstract}
As an object, the book has a material condition. On the surface, it is a collection of printed leaves held between two covers. The graphics, colours and design are aspects partaking of its aesthetic dimension. However, beyond this materiality, with all its aesthetic qualities, the book has an intrinsic capacity of undergoing changes in its status. Gabriel Liiceanu, a Romanian philosopher, argues that the book is an imploring object. It begs to be opened, read, and thus brought to life. Therefore, the book is an object with a special fate, which necessarily depends on the whims and moods of the Reader who, by merely opening and reading it, changes its ontological status, breathes life onto it and saves it from an improper state of being, as Liiceanu argues.

The book's status as an object is exceptional in this situation. As an object, the book is a treasure trove. The big drama of any book is that of being sentenced to a life in prison between its covers, while its big fortune is to become a spiritual and cultural presence in the mind and soul of the Reader.
\end{abstract}

Keywords: the book as object, materiality, aesthetic dimension, ontological status, cultural and spiritual presence

\section{On the Paradoxical Status of Books}

Since the very beginning of their existence, books have drawn attention to themselves as objects. The Sumerians engraved their cuneiforms onto clay tablets. Around the year 250 B.C. papyrus scrolls started to be made in Egypt. Later, wax tablets were used as writing surfaces. All this time, reading and writing were perceived by most of the people as occult talents in Nicholas Carr's terms (92). The oral tradition dominated culture in its entirety. 
It was only after the fall of the Roman Empire that oral tradition was dramatically broken, and the number of books and of people able to write and to read increased. However, several centuries passed until 1455, when Johannes Gutenberg changed the fate of books once and for ever. The typing process invented by him triggered a further increase in the number of books printed on paper, and a new era began in human knowledge and culture (Eisenstein 50).

Irrespective of age or their materiality, books continued to fascinate and to keep an aura of mystery about them. Those who came in contact with books and who encountered their enigmas were somehow contaminated by that aura. They were the illuminati, prophets, priests, scholars, in other words people enjoying an acknowledged social status.

Therefore, taking into account its material existence and its spiritual dimension, the book is both an object and a subject, matter and spirit, silence and speech, reality and simulacrum.

The first contact with a book is strictly material. We evaluate its size, its colours, its covers. We smell its print, we touch it and we turn its pages. Therefore, the book is an object that can be described according to certain criteria, at any moment in time. However, ontologically speaking, the book is not a mere object. It is not a chair which, much as one may use it, will not change its status of being just an object. The book is an object with a soul of its own, an object that may be brought to life when somebody opens it and starts reading the pages held between its covers.

\section{Bringing the Book to Life}

When he wrote a whole book dedicated to the people and memories he reveres, the Romanian philosopher Gabriel Liiceanu titled it Declaratie de iubire (Declaration of Love) and concluded it with the chapter "Dance with a Book," where he argues that what the book does is to bring to light realms we had no idea were there, which is why

authors are the world's most secret agents: it is not clear how they act or who they impact, nor is it clear what the outcome would be or whether what happens in the world is the direct result of their deed. The only thing that is clear is that, hidden from the world, they work to change it in the long run. $(167)^{1}$

In Liiceanu's view, this hidden treasure, likened by Celan with a message in a bottle, will not pick you. Instead of picking you, they wait to be discovered, and in this sense "the books' being is a pure act of waiting. Will anybody open them

\footnotetext{
${ }^{1}$ All quotes from Gabriel Liiceanu's book Declaraţie de iubire (Declaration of Love) were translated by Dana Bădulescu.
} 
so that they may thus start to be?" (Liiceanu 167) the philosopher wonders, meaning not only that books come into being when they are read but also that we start to be more essentially ourselves when we approach the book waiting there on the shelf to be read. Liiceanu confesses that the sight of a bookcase will always remind him of a particular scene in Tolstoy's War and peace where Natasha waits in the ballroom, fearing nobody would invite her. The encounter between the two lovers in the novel is pure chance - as chancing upon a book so often is for the reader.

Good books, books which may have a memorable impact on our lives come to us in the form of the most unexpected and pleasant surprises. They are also a form of communication and connection between the text's author and its reader / the Stranger / the Other. The English novelist E. M. Forster often spoke about authors talking to you. The American poet Emily Dickinson must have seen each and every poem she wrote as her "letter to the world." The contemporary American poet Edward Hirsch speaks about Walt Whitman's "refusal to be bound, to be circumscribed, by any hierarchical or class distinctions" (Hirsch 3). Looking into Whitman's poem "Inscriptions," Hirsch notices that the 19th century poet addresses it not to acqaintances or friends but to virtually anybody who might be interested in getting in touch and receiving its message. Thus, literature becomes a universal form of communication, connecting people across borders and ages without any obstacles, which is probably the most efficient and enduring form of connection there is.

Liiceanu speaks about books as walking sticks against which we may lean as we walk towards any place we may deem to be transcendental, and he also speaks about their role of "re-uniting" (Liiceanu 171) us with each other: through the book I can talk to somebody who is not near me in time and space. Thus, I can be the contemporary of a Latin thinker who lived two thousand years ago or an author can talk to somebody who has not been born yet. As a reader or as an author, I can be contemporary with the entire world in all its ages and spaces. Liiceanu argues that reading is based on a "long-distance seduction," an "eroticism of distances," and for him the whole culture of humanity "is essentially an erotic epidemic whose virus is the book" (Liiceanu 172).

The book's presence invites the reader to open it and to bring it to life. The relation of the book with its reader is practically similar to the relation between the old alchemist and matter. Through his entire work, the alchemist frees the spirit held captive by matter, thus searching for immortality. This analogy between the reader's gesture of opening the book and the alchemist's work is not accidental. But for the reader the book remains an inert object of many (minor) uses: it may decorate a shelf, it may cover another object, it may become a secret place among whose leaves one may hide things.

The reader's gesture of opening a book to read is vital. While the writer conceives and writes a book and the publisher publishes it, the reader breathes 
life onto it. In other words, the interaction between the reader and the book saves and redeems the book from its material condition, revealing the spiritual purpose designed by the writer in the moment of its creation. Likewise, alchemy did not entail only the act of freeing the spirit from matter and obtaining pure gold. It also impacted the alchemist, changing him spiritually, bestowing immortality upon him. Apart from the myths of immortality which used to haunt and still haunt the collective mindset today, the alchemical work, just like the reading of books, confers immortality to those who practise it. It is a special relation that frees the spirit, which thereafter lasts eternally, in a refined, polished form, like pure gold.

From this perspective, leafing through a book and reading it means acting upon it in various ways: the book starts to be, getting into a vital relation with the reader, who is thus transformed. What distinguishes the book from other objects that surround us is the fact that it starts to be only through its relation with the reader. In How to Read a Poem and Fall in Love with Poetry Hirsch argues:

Many poets have embraced the New Testament idea that "In the beginning was the Word," but I prefer Martin Buber's notion in I and Thou that "In the beginning is the relation." The relation precedes the Word because it is authored by the human. The lyric poem may seek the divine but it does so through the medium of a certain kind of human interaction. The secular can be made sacred through the body of the poem. I understand the relationship between the poet, the poem, and the reader not as a static entity but as a dynamic unfolding. An emerging sacramental event. A relation between an I and a You. A relational process. (Hirsch 5)

In fact, the book reveals its many faces according to the expectations, anxieties, personality and culture of the Reader. The book invites reading, and each reading reveals a new face. In their turn, books may be seducing, torturing, dramatic or light, obscure or mysterious, commonplace or inciting, versatile and challenging. Likewise, any encounter with a book leaves its traces upon our mind and soul. Thus, the encounter with the book stirs formidable intuitions which run deep, fantastic inferences and mysterious epiphanies. We undergo changes just as the book changes its status of mere object when we read it. Still an object, the book also becomes some sort of living being, the subject of our troubles, a silent interlocutor but extremely talkative at the same time, if challenged to be so.

This indicates the paradoxical fate of the book - that of being an object and a subject, matter and spirit at the same time. Its drama is that it may never be opened. 
Sociologists like Pierre Bourdieu would tackle this issue of the book's materiality in the social sphere from the perspective of symbolic capitals. The premise of this approach is that a book, in its condition of being an object, represents $a$ symbolic capital which may be socially manipulated and twisted in many ways. This symbolic capital ultimately points out aspects that go beyond the mere materiality of books. For instance, the book can be a symbol of wisdom, of scientific knowledge, of mystery and of the unfathomable, of social belonging, etc. Those who connect themselves to its material and spiritual dimension score social success. The priests used to possess the knowledge hidden in the religious books, and this turned them into leaders of their communities. Writers and philosophers have drawn attention to these aspects, and some have managed to vanquish time. The point of the matter is that the extraordinary symbolic capital of books may be converted. This social, professional, political or cultural conversion impacts the lives of many in obvious ways. In this case, we identify two types of conversion of the book as an important symbolic property of the whole society, from its very onset. These two types indicate the paradoxical nature of books.

\section{Positive Conversions and Redeemed Books}

For some of of us, the encounter with a (certain) book may be life-changing. It may change the route of our life, our way of being and thinking. It may place us on another spiritual and social orbit. Those are the happy situations when, for instance, the scholars or book experts manage to convert their passion and knowledge based on books into a social status. Those people become role models for many other people. This happened in societies in which the book had an elitist character, and the contact with it contaminated them with their spirit. For those societies, book knowledge, a solid cultural background grounded in tradition, a certain system of values had an unquestionable significance. The book was a benchmark, it oriented lives.

We have not completely lost this paradigm today, but its connotations have changed. Today, the symbolic freight of books is converted in a way that is informative rather than formative. This holds true especially about one's relation and interaction with the scientific books. Since access to books, and implicitly to knowledge, has been democratised, the symbolic capital of books has been affected in its turn. The aspect that is truly valorised is quantity, information, while quality counts much less. Yesterday's scholars are today's experts. The interaction with the book has lost its ineffable, sacred and mysterious dimension. It has become desacralised and utilitarian instead. Nowadays, the book helps us to acquire knowledge of a practical nature, which assists us in solving concrete problems or in learning skills that are socially acknowledged. Even so, the book is a saved object. Its encounter with the contemporary individual, who is urged 
by pragmatic interests and goals, but also by a certain curiosity, is still positive, and the book gets its share of life after all. In this context of devouring pragmatism there is a certain category of readers who, like the alchemist of yore, dwell on the pages of the book in the privacy of their room, hoping that they will eventually extract from them the mind's pure gold and the eternity of the spirit. As a matter of fact, these superb fools of today's world save a culture which set in its very centre a fascinating object: the book.

\section{Dubious Conversions and Failed Books}

Of course, there are contentious situations when the social conversion of books fails to go beyond the border of their materiality, when the interaction is purely formal and the leaves are never touched. This is a matter of intellectual fraud and social simulacra. Two examples will do to make a point of it. In communist Romania, the elites, i. e. the party nomenclature, lacked a well-shaped cultural and professional background. Culture was the missing pawn on the chess-board of their social prestige. That was sorted out through an economic investment, which, they thought, did the trick. Some people in the then nomenclature would order books by the yard or complete editions from book shops. Practically, they had no interest in the book titles, author names or book contents. Their main goal was to cram their bulky bookcases with books. The mere presence of books in their homes would be an evidence of their supposedly serious cultural inclinations. This is a dubious conversion of books which were doomed, books which never managed to go beyond their stage as objects. They were silent props which enjoyed nothing else but the attention of diligent housekeepers who would dust them. This does not mean that there were no intellectually inclined persons, who knew their books, in the state and party system. On the other hand, those who lived in those days put their lives or their careers in jeopardy if they possessed or if they read books that were forbidden by the communist regime.

Another more recent example describes an equally dubious conversion of the book in the social sphere. Today, persons who own economic, social or political capital feel frustrated when it comes to their intellectual and cultural formation. The $\mathrm{BA}, \mathrm{MA}$ and $\mathrm{PhD}$ certificates are the perfect solution for bridging gaps in social prestige. These take a fairly long period of study, day and night, accumulation of knowledge, a solid background. In reality, in their case, the interaction with the book is purely formal, sparse and superficial. They become certificate owners in an educational system which abandoned the principle of competence and excellence. Economic efficiency, the number of programmes, getting a job, citations and academic project labour are the benchmarks of quantifiable academic performance nowadays. In such a system, where the lack of supplementary effort and genuine intellectual curiosity rule, 
the interaction with the book is marked by mediocrity, formality and circumstance. Of course, this is a missed encounter, in which the book fails to go beyond its own materiality. At most, it enters a comatose stage, and the individual, despite the competences attested by diplomas and certificates converted and twisted at one's will, remains mediocre and dull. Those experts are spirits of shallow waters wearing masks that cannot hide their grotesque faces lurking beneath. Of course, this scenario of two different ages makes us think of and question the social and spiritual disesases caused by the dubious conversion of books.

\section{Judging a Book by Its Covers}

To paraphrase E. M. Forster's lament about the novel telling a story, let us admit it: the book may be perceived as an object - a collection of printed leaves between two covers. In The Clothing of Books Jhumpa Lahiri reflects on their material aspect, judging books by their covers. Looking at book jackets, she argues that they become part of the book. As far as the covers of her own first published books are concerned, Lahiri confesses that, at times, she has to accept them without liking them, and although she lets it happen, she eventually feels afflicted and resentful on that account. As she sees it, a cover marks the birth of the book, and at the same time the end of her endeavour as a writer. What the cover means, both for the writer and for the readers, is that the book is accomplished and definitive.

According to Lahiri in The Clothing of Books, the cover has a "metamorphic function," transforming the text "into an object, something concrete to publish, distribute, and, in the end, sell" (Kindle Edition). The writer does not see it as necessarily good news. The material aspect of the book seems to harden, and the cover becomes a sort of heavy armour or shield, which makes it feel vulnerable, not protected.

Lahiri likens this process of encapsulating a book into a visual image to translation: the words of the book are translated into an image that suggests its overall meaning, its most essential message, and like translation, a cover can be faithful or unfaithful to the words in the book.

An excellent example of harmony between books and their covers is the collaboration between two sisters, Virginia Woolf and Vanessa Bell, a writer and a painter of the first decades of the 20th century. After Virginia and Leonard Woolf purchased a press of their own, which they named Hogarth, the two sisters started to work together: Virginia wrote sketches, short stories, essays and novels, and Vanessa illustrated them. As a matter of fact, Virginia had developed a keen interest in bookbinding ever since her adolescence. Putting all her mind, body and soul into reading, and looking at books as beautiful objects, Virginia spoke about them in her essay "How Should one Read a Book ?" as 
"made of tiny little words, which a writer shapes, often with great difficulty, into sentences of different lengths, placing one on top of another, never taking his eye off them, sometimes building them quite quickly, at other times knocking them down in despair, and beginning all over again.”

For Virginia, like for Henry James before her, writing was literally a mason's or an architect's trade, which she considered in its most material aspects. That view had a clear impact upon the very design of her books, which were illustrated by her sister Vanessa.

The sisters started their collaboration in 1919, when Hogarth published Vanessa's woodcut prints of Virginia's text "Kew gardens.” In that book, Vanessa's exquisite prints blend with Virginia's words, and the interfusion of words and visual design creates and suggests a fluidly feminine atmosphere. Thus, the two sisters' collaborative work engaged the words of Virginia's text and Vanessa's drawings in a dialogue. The collaboration continued, and in 1921, Virginia published Monday or Tuesday, a collection of experimental short stories, comprising woodcuts by Vanessa. Hogarth gave the two sisters a creative space, and year after year Virginia wrote texts and Vanessa captured their spirit in her covers, although she did not always finish reading her sister's books.

\section{Writing on Skin}

Paper derives from vegetal matter, so in order to obtain it the bodies of trees or grasses are sacrificed. Animal vellum can be more durable than paper. Vellum is a high-quality form of parchment, and it originally meant calfskin. Like parchment, the skin is prepared to take writing in ink. Before paper became available, vellum was one of the standard writing surfaces used in Europe. Mediaeval manuscripts, some Buddhist texts, and all Sifrei Torah texts are written on vellum or alternatives. Even a quarter of the 180 copy edition of Gutenberg's first Bible was printed on vellum in 1455 because it was supposed to be the best writing surface for a high-quality book. Vellum continued to be used for high-status documents because it lasts longer than paper.

In her volume of poems The Getting of Vellum the Irish poet Catherine Byron evokes the animal materiality of the vellum with a mixed sense of guilt, awe and veneration for the sacrifice. Starting from the casual gesture of writing a telephone number or a name "on the handy back of your skin," the poem moves gradually towards the "lamb, or kid, or calf, / whose skin has been stripped off, /scraped clean of life's paraphernalia, and transformed, even transfigured, into parchment / or in the case of the calf vellum / for the writing of the Word' (Byron 27). That 'transformation' or 'transfiguration' is a second birth, and the poet feels a frisson of bitter sadness at the sight of it, which mingles with a sense of beauty and even joy at the thought that the sacrifice of 
the animal's life, which is limited, serves the writing of the enduring Word of the Lindisfarne Gospels, an illuminated book produced around the year 700, which is now on display in the British Library in London.

In some cultures, the painful inscription on skin is part of a scenario of initiation. In her book The Woman Warrior, the Chinese-American writer Maxine Hong Kingston describes the ritual of writing on human skin in the story of $\mathrm{Fa} \mathrm{Mu} \mathrm{Lan,} \mathrm{who} \mathrm{needs} \mathrm{to} \mathrm{undergo} \mathrm{it} \mathrm{unless} \mathrm{other} \mathrm{people} \mathrm{or} \mathrm{even} \mathrm{herself}$ should ever forget the message, and so that enemies should also see it written on her skin. The episode of FaMu Lan's skin being chiseled has an almost hypnotic effect upon the reader:

My father first brushed the words in ink, and they fluttered down my back row after row. Then he began cutting; to make fine lines and points he used thin blades, for the stems, large blades.

My mother caught the blood and wiped the cuts with a cold towel soaked in wine. It hurt terribly - the cuts sharp; the air burning; the alcohol cold, then hot - pain so various. I gripped my knees. I released them. Neither tension nor relaxation helped. I wanted to cry. If not for the fifteen years of training, I would have had to be held down. The list of grievances went on and on. If any enemy should flay me, the light would shine through my skin like lace.

At the end of the last word, I fell forward. (Hong Kingston 35)

Sometimes, writing on human skin is the only way in which people can communicate. In one of the episodes of The Book of Whispers, the Romanian writer of Armenian origin Varujan Vosganian invokes the moment when a young boy's skin is inscribed in cautious secrecy, after which he is dispatched as a courier from one "circle of death" to another during the Armenian genocide of 1915, with the vital information written on his skin stretched on the bones.

\section{The Ritual of Learning to Read and Emerson's Dream of Eating the World $^{2}$}

In A History of Reading, Alberto Manguel argues that in literate societies, learning to read is "a ritualized passage out of a state of dependency and rudimentary communication” (Manguel 71). Thus, in these societies, every child who learns to read enters the collective memory by way of books, renewing it by the act of reading.

More often than not, the ritual entails a very concrete transfer of the book's bones, sinews, tissues, blood and skin, i. e. its letters in ink on vellum or

\footnotetext{
${ }^{2}$ For a discussion of related aspects, please see Dana Bădulescu, "On Emerson's Dream of Eating the World" in Linguaculture, Volume 9, Number 2, 2018 (http://journal.linguaculture.ro/images/2018-2/LINGUACULTURE-2-2018-04Badulescu.pdf)
} 
paper, onto the child's own body. Manguel writes about the ritual of learning to read in the medieval Jewish society, in which, on the Feast of Shavuot, which celebrates the moment when Moses received the Torah from the hands of God, the boy to-be-initiated would be wrapped in a prayer shawl and taken by his father to the teacher. After being sat on the teacher's lap, with its suggestions of bodily transfer, the child was shown a slate with the Hebrew alphabet, a passage from the scriptures and the words "May the Torah be your occupation." The teacher read out every word for the child to repeat, and then the slate was smeared with honey "and the child licked it, thereby bodily assimilating the holy words. Also, biblical verses were written on peeled hard-boiled eggs and on honey cakes, which the child would eat after reading the verses out loud to the teacher" (Manguel 71).

Arguing that we read in "search for a difficult pleasure" and speaking about "a reader's Sublime," which "seems the only secular transcendence we can ever attain" (29), Harold Bloom formulates an aesthetic approach to the pleasure of reading. In its complexity, the reader's pleasure is a combination of intellectual, emotional and physical engagement with the book. In his essay "Is Nothing Sacred?”, Salman Rushdie speaks about having been born and raised in a family where everybody cherished books. Recalling that, when he was a child, he often had to kiss books in case he dropped them, Rushdie also remembers how he grew aware of the fact that, as bread is food for the body, books are food for the soul (Rushdie 415).

The very physical act of either ingesting the book or even getting engaged in an erotical relationship with it suggests several aspects: the materiality of the book, the material nature of the readers' engagement in the book, and also the readers' need to appropriate the book in the most concrete way in order to commit it to their memory. Thus, the book is shared, and its contents are transferred.

It is the idea that books are actually the world that animated the 19th century American essayist Emerson when he wrote a passage which the American poet Edward Hirsch used as a motto for his book How to Read a Poem and Fall in Love with Poetry: "I dreamed that I floated at will in the great Ether, and I saw this world floating also not far off, but diminsihed to the size of an apple. Then an angel took it in his hand and brought it to me and said, "This must thou eat.” And I ate the world.”

\section{The Beauty of "the Naked Book"}

Not being always happy with the covers of her books, Jhumpa Lahiri states that in today's world the function of the book's cover "is much more commercial than aesthetic." Lahiri finds the blurb, the list of past awards, honours, other titles, quotes from critics that appear on the covers, etc. a cumbersome deterrent, 
a kind of list of ingredients that merely sells the book as a product. I cannot help associating this with a critic's remark when he introduced a book to a festival of literature and translation a few years ago: why should the book come in a plastic wrap, which by the way, makes it look like cheese or sausage or salami?

Lahiri remembers the days of her childhood, when she "would go to the library, where books were often undressed: without jackets or any images." Those "naked books," Lahiri recalls, "had an anonymous quality, secretive" (Lahiri Kindle Edition). One is struck by the truth of that: without the author's photograph, a blurb, an indication of printing number or edition, the naked book lies there in the Readers' hands for them to judge its naked and timeless beauty.

\section{Coda}

There is no doubt that the contact with the book as a mere object stirs epidermic, smelling, visual and bodily reactions within us. It asks for a variety of postures, it exhales a smell of fresh print or of pages yellowed with age, it enchants the eye with playful images or it lets it dwell in simple contours. It is a rich experience of the senses, which grows even larger and more complex when we open the book and start a dialogue with it. This dialogue of the senses is completed by a mental dialogue, which is a consequence of our act of reading. The cogs of our mind are set in motion as we start deciphering the message. However, the contact with the book also stirs an emotional dialogue. It makes us shed tears, it makes us smile, it unleashes joys of so many kinds. But above everything, the interaction with the book touches the spirit and engages it in a secret dialogue. Ultimately, the book is a paradoxical and absolutely charming creation, whether naked or clothed.

\section{References}

Bloom, Harold. How to Read and Why. New York: Scribner. 2000. Print.

Bourdieu, Pierre. Economia bunurilor simbolice, București: Meridiane. 1986. Print.

Byron, Catherine. The Getting of Vellum. Salmon Poetry. 2001. Print.

Carr, Nicholas. Superficialii. Efectele internetului asupra creierului uman, București, Editura Publică. 2012. Print.

Eisenstein, Elizabeth L. The Printing Press as an Agent of Change: Communications and Cultural Transformations in Early-modern Europe. Cambridge: University Press. 1979. Print.

Hirsch, Edward. How to Read a Poem and Fall in Love with Poetry. New York: Harcourt, Inc. 1999. Print.

Hong Kingston, Maxine. The Woman Warrior. Memoirs of a Girl Among Ghosts. New York: Vintage International, Vintage Books. 1989. Print.

Lahiri, Jhumpa. The Clothing of Books. New York: Vintage. 2016. Kindle Edition. 
Liiceanu, Gabriel. Declaraţie de iubire, Bucureşti: Humanitas. 2001. Print. Manguel, Alberto. A History of Reading. London: Flamingo. 1997. Print.

Rushdie, Salman. Imaginary Homelands. Essays and Criticism 1981-1991. Penguin Books. 1992. Print.

Varujan, Vosganian. Cartea şoaptelor. Iaşi: Polirom. 2009. Print.

Woolf, Virginia. "How Should One Read a Book?” https://www.nottinghilleditions.com/wp-content/uploads/2014/11/NHE-WoolfHowShouldOneReadABook.pdf. Web. 20 April 2020.

\section{BIONOTES}

Dana Bădulescu teaches modernist and postmodernist British and American literature, basic elements of literary theory and critical thinking, transculturalism and translations, at "Alexandru Ioan Cuza" University of Iaşi. She has published a series of articles on modernism and postmodernism, key modernist and postmodernist writers and texts. In December 2014, she formed a national research network which joined ISCH COST Action IS 1404 "Evolution of reading in the age of digitisation (E-READ)," which focused her research on books and reading, an interest she has been keen on pursuing in a series of articles on this topic written and published in the last six years.

E-mail: dnbadulescu@gmail.com

Cristina Gavriluţă teaches at the Faculty of Philosophy and Social and Political Sciences, "Alexandru Ioan Cuza" University of Iaşi. She was a doctoral and postdoctoral grantee doing her research in France (Sorbonne, Ecole des Hautes Etudes en Sciences Sociales) and Italy ("G. D’Anunzio” University). Her research interests are: social and cultural anthropology, deviance sociology, the sociology of social change, ethnology. She coordinates and she is also a member of the research team of several grants such as: Evolution of Reading in the Age of Digitisation (EREAD); Children of Prisoners, Interventions \& Mitigations to Strengthen Mental Health, Leaders of Tomorrow, Voters of Tomorrow: Together for a Better Politics. She has authored many studies and articles in proceedings and in prestigious magazines, and she coordinated several volumes on topical issues: Cărțile care ne dau aripi / The Books that Make Us Fly (2019), Sociologia la Alma Mater Iasiensis. In honorem profesor Vasile Miftode (2017), Interdisciplinary Approaches to Social Sciences (2013) Human Trafficking. Secularization and Public Policy Intervention (2013). She is also the single author of five volumes: Negativul cotidianului / The Negative of the Everyday ( 2017), The Everyday Sacred. Symbols, Rituals, Mythologies (2013), Socioantropologia fenomenelor divinatorii / The Socioanthropology of Divination (2008), Sacrul şi californizarea culturii / The Sacred and the Californisation of Culture (2008), Socioantropologia fenomenului religios / The Socioanthropology of the Religious Phenomenon (2003).

E-mail: cristina_gavriluta@yahoo.fr 